\title{
Nikolaus Overtoom. "A Reconsideration of Mithridates II's Early Reign: A “Savior” Restores the Eastern Frontier of the Parthian Empire"
}

\section{Leonardo Gregoratti}

\section{(2) OpenEdition Journals}

Electronic version

URL: https://journals.openedition.org/abstractairanica/53323

DOI: 10.4000/abstractairanica.53323

ISSN: 1961-960X

Publisher:

CNRS (UMR 7528 Mondes iraniens et indiens), Éditions de l'IFRI

\section{Electronic reference}

Leonardo Gregoratti, "Nikolaus Overtoom. "A Reconsideration of Mithridates II's Early Reign: A "Savior" Restores the Eastern Frontier of the Parthian Empire"', Abstracta Iranica [Online], Volume 42-43 | 2021, document 56, Online since 30 December 2021, connection on 18 December 2022. URL: http:// journals.openedition.org/abstractairanica/53323 ; DOI: https://doi.org/10.4000/abstractairanica. 53323

This text was automatically generated on 18 December 2022.

All rights reserved 
Nikolaus Overtoom. "A Reconsideration of Mithridates II's Early Reign: A “Savior" Restores the Eastern Frontier of the Parthian Empire"

\author{
Leonardo Gregoratti
}

\title{
REFERENCES
}

Nikolaus Overtoom. "A Reconsideration of Mithridates II's Early Reign: A “Savior" Restores the Eastern Frontier of the Parthian Empire”, Parthica, 21, 2019, p. 43-55.

Overtoom, a specialist of the early Parthian empire, in this paper deals with the political and historical significance of Great King Mithridates II and his role in strengthening the kingdom after a period of crisis. Before his accession to the throne, Parthia had to face powerful local lords in the newly acquired Mesopotamian territories not keen on renouncing their power and the increasing threat of the Central nomadic invasions in the east that had already cost the lives of two Great Kings. Immediately after having assured the power, Mithridates managed to subdue the Mesopotamian kingdom of Characene before moving east to face the nomadic threat. He left his generals to rule Mesopotamia, a choice that did not solve all the problems considering the need for a later royal intervention to substitute the appointed officers and pacify the province again. Still, the west's victories allowed Mithridates to focus on a vast scale and long campaign in the east. He defeated the nomad tribes and chased them in Bactria and Sogdiana, occupying part of the former to use it as a solid base to prevent further incursions from the east. Having neutralised the nomadic danger and 
consolidated the empire, he coined coins claiming rightly for himself the title of "Saviour".

\section{AUTHORS}

\section{LEONARDO GREGORATTI}

Durham University 